\title{
Translated Poetry in Brazil 1965-2004
}

John Milton

Universidade de São Paulo

Por meio de uma pesquisa quantitativa, este artigo analisa a tradução de poesia publicada no Brasil entre 1965 e 2004, enfatizando o grande interesse por parte de editoras e do público na sua publicação e demonstrando que São Paulo é a cidade onde mais se traduz poesia. Também mostra que o mercado concentra-se em obras clássicas, especialmente as de língua inglesa, e que a tradução de poesia é essencialmente uma atividade praticada por homens.

Through a quantitative survey, this paper will examine the translation of poetry in Brazil in the last forty years, comparing poetry translated from English with poetry translated from other languages, showing the considerable growth in this area, and demonstrating that translated poetry can be considered a new genre in Brazilian literature. In order to do this, I attempted to discover translations of poetry published between 1965 and 2004, including reeditions of previously published works.

\section{The Survey}

I firstly made a quantitative survey of the translations made into English. Table 1 shows the number of translations made from English by translator:

Table 1: Number of Translations by Translator

\begin{tabular}{lc}
\hline Translator & Number \\
\hline Paulo Vizioli & 12 \\
Augusto de Campos & 8 \\
Jorge Wanderley & 4 \\
Paulo Henriques Britto & 4 \\
Péricles Eugênio da Silva Ramos & 4 \\
Alípio de Corrêa Franca & 3 \\
Ivan Junqueria & 2 \\
Alberto Marsicano & 2 \\
José Paulo Paes & 2 \\
Rodrigo Garcia Lopes and Maurício Arruda Mendonça & 2 \\
Idelma Ribeiro de Faria & 2 \\
\hline
\end{tabular}


Thus we can see Paulo Vizioli as the most productive translator in terms of translations from English, to a great extent through the fact that as Catedrático of the area of English Literature at the Universidade de São Paulo, he only translated works from English.

This picture changes somewhat when we include works from other languages:

Table 2: Translated works by translator: all languages

\begin{tabular}{lc}
\hline Translator & Number \\
\hline Paulo Vizioli & 12 \\
Augusto de Campos & 11 \\
Haroldo de Campos & 7 \\
Alberto Marsicano & 5 \\
Decio Pignatari & 4 \\
Jorge Wanderley & 4 \\
Paulo Henriques Britto & 4 \\
Péricles Eugênio da Silva Ramos & 4 \\
José Paulo Paes & 4 \\
Alípio de Corrêa Franca & 3 \\
Ivan Junqueira & 3 \\
\hline
\end{tabular}

Paulo Vizioli is still the translator with the highest number of translations, but now it is possible to have an idea of the considerable production of Augusto and Haroldo de Campos.

Table 3 shows the number of translations from English by publishing company:

Table 3: Number of translations by publishing house - English

\begin{tabular}{lc}
\hline Publisher & Number \\
\hline Companhia das Letras & 11 \\
Iluminuras & 6 \\
L\&PM & 6 \\
Nova Fronteira & 5 \\
Nova Alexandria & 4 \\
Civilização Brasileira & 4 \\
\hline
\end{tabular}


Companhia das Letras leads, followed by Iluminuras and L\&PM. The marketing policy of the houses is very different: Companhia das Letras specializes in extremely well produced products with high-quality finishing. Visually, the Companhia das Letras works are very attractive, and it seems that Iluminuras has been trying to emulate Companhia das Letras to a great extent, with visually attractive works. By contrast, L\&PM markets its works through news stands, press run is higher, usually around 10,000 , and the finished product is of poorer quality, selling at $25 \%$ to $40 \%$ of the cost of the Companhia das Letras translations, $\mathrm{R} \$ 8-\mathrm{R} \$ 12$, as against approximately $\mathrm{R} \$ 30$ for Companhia das Letras products.

Table 4 extends this to books translated from all languages:

Table 4: Number of translations by publishing house - all languages

\begin{tabular}{lc}
\hline Publisher & Number \\
\hline Iluminuras & 22 \\
Companhia das Letras & 15 \\
Nova Fronteira & 13 \\
L\&PM & 12 \\
Perspectiva & 6 \\
Nova Alexandria & 4 \\
Civilização Brasileira & 4 \\
\hline
\end{tabular}

In numerical terms we can clearly see the dominance, at least in numerical terms, of Iluminuras, which publishes works from a variety of languages. The Companhia das Letras policy seems to favour translations from English, whereas Iluminuras seems to be open to a wide range of languages. The other leading houses are Nova Fronteira, with a number of classic translations such As Grandes vozes líricas hispano-americanas, translated by Aurélio Buarque de Holanda Ferreira, Baudelaire's As flores do mal, translated by Ivan Junqueira, his Pequenos poemas em prosa, translated by Aurélio Buarque de Holanda Ferreira, and José Lino Grünewald's translation of Mallarmé.

Perspectiva also plays a major role in the area, having published a number of translations of the Campos brothers, including Poesia Russa Moderna, Mallarmé and Maiakóvski.

Table 5 shows city of publication for translations from English: 
Table 5: City of publication: translations from English

\begin{tabular}{lc}
\hline City & Number \\
\hline São Paulo & 46 \\
Rio de Janeiro & 23 \\
Porto Alegre & 5 \\
Florianópolis & 3 \\
Belo Horizonte & 2 \\
Mariana & 1 \\
\hline
\end{tabular}

Both Companhia das Letras and Iluminuras are in São Paulo, and we can clearly see that the houses are now dominant in the area, where it seems that the emphasis has switched from Rio de Janeiro to São Paulo. José Olympio, which has now been subsumed into the Record conglomerate, is no longer a major force in literary translation, and, in Rio de Janeiro, only Nova Fronteira is a major player.

The table clearly shows a dominance of São Paulo and Rio de Janeiro. Porto Alegre is mainly represented by L\&PM, and other small provincial houses occasionally publish poetry in translation.

Table 6 shows city of publication for all languages:

Table 6: City of publication: all languages

\begin{tabular}{lc}
\hline City & Number \\
\hline São Paulo & 110 \\
Rio de Janeiro & 39 \\
Porto Alegre & 12 \\
Brasília & 3 \\
Florianópolis & 3 \\
Belo Horizonte & 2 \\
Mariana & 1 \\
\hline
\end{tabular}

The dominance of São Paulo is emphasized even further, particularly due to the large number of titles published by Iluminuras, and the lack of any Carioca counterpart of Iluminuras.

Table 7 shows the nationality of the original author: 
Table 7: Nationality of original author (TS Eliot excluded)

\begin{tabular}{lc}
\hline Nationality & Number \\
\hline British & 30 \\
American & 25 \\
Irish & 5 \\
Portuguese & 1 \\
Trinidadian & 1 \\
\hline
\end{tabular}

There is a somewhat surprisingly large number of North American authors translated, in proportion to British authors. This fact is borne out when we examine the number of 20th century poets translated:

Table 8: Nationality of original author - 20th century works (TS Eliot excluded)

\begin{tabular}{ll}
\hline Nationality & Number \\
\hline American & 17 \\
British & 4 \\
Irish & 3 \\
Trinidadian & 1 \\
\hline
\end{tabular}

Why have 20th century American authors been much more popular to translate than their British counterparts? It seems that two groups of American poets have found particular favour in Brazil: modernists such as Marianne Moore, William Carlos Williams and Ezra Pound, who have been of great importance for theory of Augusto and Haroldo de Campos; and secondly, the Beat poets, Allen Ginzberg, Charles Bukovski, Lawrence Ferlinghetti and Gregory Corso, extremely popular during the 1960s and 1970s, when open defiance of the military regime was often difficult and could result in violent repression, and the radical Beat culture coming from the US may have captured much of the energy which could not protest in Brazil.

Table 9 compares the number of works by original language: 
Table 9: Original language of works translated

\begin{tabular}{lc}
\hline Language & Number \\
\hline English & 62 \\
French & 24 \\
Spanish & 18 \\
Italian & 8 \\
German & 6 \\
Latin & 5 \\
Modern Greek & 2 \\
Japanese & 2 \\
Russian & 2 \\
\hline
\end{tabular}

This table is further proof of the dominance of English as a foreign language in Brazil. Of the 18 works translated from Spanish, seven are of works by a Chilean, Pablo Neruda, four are from Argentina, one by a Nicaraguan, Ernesto Cardenal, and one from Colombia; and all the Spanish poetry translated is by Lorca.

Nearly half of the translations which have been made from English are of 20th century poetry, with very little early poetry translated:

Table 10: Century of original work - translations from English

\begin{tabular}{cc}
\hline Century & Number \\
\hline 20 & 30 \\
19 & 16 \\
18 & 5 \\
17 & 4 \\
16 & 5 \\
before & 3 \\
\hline
\end{tabular}

This is again borne out when we include translations from languages other than English: 
Table 11: Century of original work - translations from English

\begin{tabular}{cc}
\hline Century & Number \\
\hline 20 & 64 \\
19 & 13 \\
18 & 6 \\
17 & 4 \\
16 & 5 \\
before & 21 \\
\hline
\end{tabular}

However, the difference here is the presence of a large number of older classic works, such as the poetry of Sappho, Villon, Horace, Homer and Dante, which have achieved canonical status.

Despite the female dominance of university translation courses, and certain other areas of the translation profession, poetry is something of a male domain, both in terms of poets translated and of translators:

Table 12: Sex of authors: translations from English

\begin{tabular}{lc}
\hline Sex & Number de authors \\
\hline Male & 43 \\
Female & 5 \\
\hline
\end{tabular}

Table 13: Sex of translators: translations from English

\begin{tabular}{lc}
\hline Sex & Number de authors \\
\hline Male & 44 \\
Female & 11 \\
\hline
\end{tabular}

Table 13 shows a higher number of female translators than female authors, but poetry translation is heavily dominated by men.

Similar figures, with an even lower percentage of female translators, are found when we include translations from all languages:

Table 14: Sex of authors: all languages

\begin{tabular}{lc}
\hline Sex & Number \\
\hline Male & 115 \\
Female & 14 \\
\hline
\end{tabular}


Table 15: Sex of translators: all languages

\begin{tabular}{lc}
\hline Sex & Number \\
\hline Male & 124 \\
Female & 23 \\
\hline
\end{tabular}

\section{Further Analysis}

A large number of gaps can be found: areas where one would expect to find authors who have been translated as they have been canonized in the home culture. There is very little early poetry in English translated, and no Anglo-Saxon poetry. Certain major poets have no anthology: there is no volume of Ben Jonson, Sir Philip Sidney or Edward Spenser in Portuguese. Other major poets have had only a small part of their work translated: Browning is represented only by The Pied Piper of Hamlin; Shelley has no anthology, only The Triumph of Life; Byron only has Beppo in Portuguese; Tennyson only appears in an anthology of 19th century poetry. Likewise, there are considerable gaps in British 20th poets translated, with no DH Lawrence, Thomas Hardy, Wilfred Owen, Siegfried Sassoon, AE Housman, Walter de la Mare or Philip Larkin.

Likewise, in other languages there are very big gaps: for example, no volume of contemporary Spanish or German poetry has been published; very little from any literature in the 18th century has been published; and no pre-20th century Russian poetry has been published.

Certain clusters of poets have been translated. In the English language, Pound (3) and Eliot (5) would form one cluster, and they can be linked to another of American modernists: Moore, Stevens, Williams and Bishop. A third cluster would be that of the Beat poets: Ferlinghetti, Bukovski, Corso and Ginsberg. Donne has been translated twice, and José Paulo Paes also published a volume of Metaphysical Poetry. A further group would be that of the "rebel" poets: Blake; the Beats and Whitman, who were all published in the L\&PM "Rebeldes Malditos" series. A final cluster is that of Eastern European poets, who are being published in a series begun by the Universidade de Brasília, the Coleção Poetas do Mundo, edited by Henryk Siewierski, who is from Poland.

Although there is a large number of gaps, there are also a number of authors who have been translated by more than one translator: Blake, Bishop, Keats, Poe, Dickinson, Whitman, Milton, Shakespeare, Plath, 
Baudelaire, Mallarmé, Ungaretti, Lorca and Neruda all fall into this category. Indeed it seems that the work of certain poets acts almost as a field of contention between translators, anxious to show their ability and possibly to "defeat" rivals. Thus we can see the sonnets of Shakespeare, Les Fleurs du Mal of Baudelaire, and Poe's The Raven as open territory where translators challenge and emulate previous translations.

This point can be seen in many of Haroldo de Campos' prefaces, where he emphasizes the fact that his translation will be an improvement on what has already been done. A good example is his Postface to Deus e o Diabo no Fausto de Goethe, where he favourably compares his own translation of Goethe with that of Agostinho d'Ornellas and Jenny Klabin Segall (HAROLDO DE CAMPOS, 1981, p.186 passim).

Rosemary Arrojo emphasizes this point in her article on the translations of Augusto de Campos and Paulo Vizioli, where she sees their translations of the poems of John Donne as the field where very differing attitudes to the English poet can be seen at play (ARROJO, 1984).

Such challenges can even become aggressive, as exemplified in the cutting critique of Augusto de Campos' translation of Hart Crane's "Praise for an Urn" by Bruno Tolentino on 3 September 1994. Augusto replied to Tolentino equally strong language in the following edition of the Estado de São Paulo, supported by a petition signed by some 70 São Paulo intellectuals plus entertainers such as Caetano Veloso and Gilberto Gil. Augusto also demanded that João Moura Jr, the editor of the Cultural Supplement of the Estado be fired. The discussion continued in the pages of the Folba de São Paulo for the next month (MILTON, 1996).

On the other hand, certain authors have their "owners", translators who are recognized as authorities in translating that particular poet, thereby making it difficult for other translators to encroach on this ground. Cases in point are Paulo Vizioli as translator of Chaucer and medieval English poetry; Augusto and Haroldo de Campos as translators of Pound; Alípio Franca Corrêa, who has translated two volumes of Joyce's poems "Joyce"; Paulo Britto, who has translated both Elizabeth Bishop's letters and poetry. I even find myself as a possible "owner", as together with Alberto Marsicano, I translated Keats and we are now planning to publish anthologies of Wordsworth and Shelley.

Few of the houses that publish poetry translation receive any kind of subsidy, and thus the publication of poetry in translation is very much a commercially viable enterprise. The translation of the poems 
of John Keats I made together with Alberto Marsicano is now in its third edition. The Martins Fontes translation of Lorca is in its fourth edition, and the Perspectiva Maiakóvski is in its seventh edition. Translations of recognized canonized poets such as Shakespeare, Dante and Homer sell: publication costs are often very low; most of the works of the poets published are in the public domain; translation rights, where they exist, are seldom more than a few hundred dollars; publishers often do not need to pay translators anything as the translators, unaware of the fact that publishing houses may make a considerable profit on translated poetry, will often be pleased to see their translations published, and may even pay to get their translations into print!

However, certain universities are becoming involved in the area: the Universidade de Brasilia is publishing the Coleção Poetas do Mundo. EDUSP has published Catullus and the Odorico Mendes translation of the Odyssey, which has played a major role in reestablishing Odorico Mendes as a major figure in the canon of Brazilian translators. After being severely criticized by Sílvio Romero, who considered his translations "monstruosidades", written in a macarronic Portuguese, and Antonio Cândido, who called his language decadent (MILTON, 1998, p.208), the EDUSP publication, with preface by Haroldo de Campos and introduction and notes by Antônio Medina, places Odorico in the canon of highly recognized Brazilian translators.

Not all authors published are so well-known internationally. Sometimes the exotic element may attract, as in the case of Bahsô's haikais. Anthologies also seem to be commercially viable as a number have been published from Argentina, France, Britain, Korea, Colombia and the West Indies.

Intermediaries are enormously important in deciding the direction of translated poetry. As mentioned, Henryk Siewierski, of Polish origin, was instrumental in starting the Universidade de Brasília Coleção Poetas do Mundo. Samuel Leon, from Argentina, the co-owner of Iluminuras, has published several books of Argentine poets. I now find myself in the position of possible intermediary of English poetry.

In her Ph D thesis, Irene Hirsch has shown that much American fiction translated in Brazil entered the Brazilian literary system in a rather conservative position. On few occasions did translations of North American fiction help to innovate Brazilian literature (HIRSCH, 2002). And in the 1960s and 1970s the USAID Program financed the publication of a large 
number of fictional and non-fiction works which it was in the interest of the US government to promote. However, it seems that this support did not extend to poetry. The large amount of North American poetry translated is formally innovative, as in the cases of Pound, Eliot, Moore and Williams, Whitman and Ginzberg; and, in the case of the Beat poets, is radical and anti conservative American values in social terms.

\section{Conclusion}

This study has emphasized the considerable number of works of translated poetry published from 1965 to 2004 in Brazil and proposes that this area can rightly be considered a formal genre of contemporary Brazilian literature. No longer do poets include a few translations at the back of their anthologies; instead, both poets and specialized translators publish volumes of translations of recognized foreign poets. These volumes will be bilingual, with the original facing the translation. They will usually be very well produced, often by houses like Companhia das Letras and Iluminuras, which specializes in the area, though L\&PM issues can be found on news stands. Most will be published in São Paulo, and they will nearly always be translations made by men of male authors.

\section{Bibliography: Translations from English}

\section{Anthologies}

CAMPOS, Augusto de. O Anticrítico. São Paulo: Companhia das Letras, 1986. (Donne, Fitzgerald, Emily Dickinson, Carroll).

CAMPOS, Augusto de. Verso, reverso, controverso. São Paulo: Perspectiva, 1978. (Donne, Herbert, Carew, Suckling, Crawshaw, Marvell, Blake, Hopkins. Perspectiva).

CESAR, Ana Cristina. Escritos da Inglaterra. São Paulo: Brasiliense, 1988. (Emily Dickinson).

GRÜNEWALD, José Lino. Grandes Poetas da Lingua Inglesa do Século XIX. Rio de Janeiro: Nova Fronteira, 1988.

OLIVEIRA GOMES, Aila. Poesia metafísica, uma Antologia (Shakespeare, Donne, Herbert, Vaughan, Crashaw, Marvell, King, Quarles, Cowley, TS Eliot. São Paulo: Companhia das Letras, 1991. 
SILVA RAMOS, Péricles Eugênio de; VIZIOLI, Paulo. Poetas de Inglaterra. São Paulo: Secterária Municipal de Cultura, 1971.

VIZIOLI, Paulo. Litertaura inglesa medieval. São Paulo: Nova Alexandria, 1988.

WANDERLEY, Jorge. Antologia da nova poesia norte-americana. Rio de Janeiro: Civilização Brasileira, 1992.

\section{Individual authors}

AUDEN W H. W H Auden: Poemas. Trad. João Moura Jr and José Paulo Paes. São Paulo: Companhia das Letras, 1986.

BEOWULF. Beowulf. Trad. Ary González Galvão. São Paulo: Hucitec, 1982. BISHOP, Elizabeth. Elizabeth Bishop, Poemas. Trad. Horácio Costa. São Paulo: Companhia das Letras, 1990.

BISHOP, Elizabeth. Elizabeth Bishop, Poemas. Trad. Paulo Britto. São Paulo: Companhia das Letras, 2001.

BLAKE, William. William Blake: poesia e prosa selecionadas. 3. ed. Trad. Paulo Vizioli. São Paulo: Ismael, 1984.

BLAKE, William. Escritos de William Blake. Série Rebeldes Malditos. Trad. Alberto Marsicano \& Regina de Barros Carvalho. Porto Alegre: L\&PM, 1984.

BLAKE, William. O Matrimônio entre o Céu e o Inferno e O Livro de Thiel. Trad. José Antonio Arantes. São Paulo: Iluminuras, 1995.

BLAKE, William. O Tygre, de William Blake. Trad. Augusto de Campos. Edição do autor, 1977.

BROWNING, Robert. O Flautista do Manto Malbado. Trad. Alípio Correia de Franca Neto. São Paulo: Musa, 1993.

BUKOWSKI, Charles. Os 25 Melhores Poemas de Charles Bukowski. Trad. Jorge Wanderley. Rio de Janeiro: Bertrand Brasil, 2003.

BURNS, Robert. Robert Burns, 50 Poemas, Luiza Lobo. Rio de Janeiro: Relume Dumará, 1994.

BYRON, Lord. Beppo: Uma História Veneziana. Trad. Paulo Britto. Rio de Janeiro: Nova Fronteira, 1989, 2003.

CAGE, John. John Cage: de Segunda a um Ano. Trad. Augusto de Campos. São Paulo: Hucitec, 1985. 
CHAUCER, Geoffery. Chaucer. Contos de Cantuário. Paulo Vizioli apresentação de Contos da Cantuária. São Paulo: Queiroz, 1991.

COLERIDGE, Samuel Taylor. Coleridge - Poemas e Excertos da biografia literária. Paulo Vizioli. São Paulo: Nova Alexandria, 1995.

CORSO, Gregory. Gregory Corso: Gasolina e Lady Vestal. Porto Alegre: L\&PM, 1984.

CORSO, Gregory. Cartas Extraviadas e outros poemas. Porto Alegre: L\&PM.

CREELEY, Robert. Poemas. Regis Bonvicino. São Paulo: Ateliê, 1997.

CuMmings, E E. Dez Poemas de e.e. cummings. Rio de Janeiro: Serviço de Documentação, MEC, 1960.

CUMMINGS, E E. 20 POEM(A)S - E.E. CUMMINGS. Florianópolis: NoaNoa, 1979.

CUMMINGS, E. E. e e. cummings 40 POEM(A)S, Augusto de Campos. São Paulo: Brasiliense, 1986.

CuMMInGS, E E. P O E M (A) S. Trad. Augusto de Campos. Rio de Janeiro: Francisco Alves, 1999.

DICKINSON, Emily. Emily Dickinson: uma centena de poemas. Trad. Ailá de Oliveira Gomes. São Paulo: Queiroz/EDUSP, 1985.

DONNE, John. John Donne, O Poeta do Amor e da Morte. Trad. Paulo Vizioli. São Paulo: Ismael, 1985.

DONnE, John. John Donne, o Dom e a Danação. Trad. Augusto de Campos. Florianópolis: NoaNoa, 1978.

DURRELL, Lawrence. Poemas. Trad. Jorge Wanderley. Rio de Janeiro: Topbooks, 1995.

ELIOT, T S. TS Eliot, Poesia. 3. ed. Trad. Ivan Junqueira. Rio de Janeiro: Nova Fronteira, 1981.

ELIOT, T S. TS Eliot - Poemas 1910/1930. Trad. Idelma Ribeiro de Faria. São Paulo: Massao Ohno, 1985.

ELIOT, T S. T S Eliot \& Charles Baudelaire. Poesia em Tempos de Prosa. Trad. Lawrence Flores Pereira. São Paulo: Iluminuras, 1996.

ELIOT, T S. T S Eliot, Quatro Quartetos. Trad. Ivan Junqueira. Rio de Janeiro: Civilização Brasileira, 1997. 
ELIOT T S. TS Eliot, Emily Dickinson. René Dupestre, Seleção. Trad. Idelma Ribeiro de Faria. São Paulo: Hucitec, 1992.

FERLINGHETTI, Lawrence. Um parque de diversões da cabeça. Trad. Eduardo Bueno \& Leonardo Fróes. Porto Alegre: L\&PM, 1984.

GINSBERG, Allen. Allen Ginsberg. Uivo. Tr. Claudio Willer. Porto Alegre: L\&PM, 1984.

GINSBERG, Allen. A queda da América. Porto Alegre: L\&PM, 1985.

HEANEY, Seamus. Seamus Heaney, Poemas. Trad. José Antonio Arantes. São Paulo: Companhia das Letras, 1998.

HOPKINS, Gerald Manley. Gerald Manley Hopkins. Poemas. Trad. Ailá de Oliveira Gomes. São Paulo: Companhia das Letras, 1989.

HOPKINS, Gerald Manley. Hopkins: a Beleza Difícil. São Paulo: Perspectiva, 1997.

HUGHES, Ted. Ted Hughes, Cartas de Aniversário. Trad. Paulo Britto. Rio de Janeiro: Record, 2001.

JOYCE, James. Joyce. Poemas, um tostão cada. Trad. Alípio Correia de Franca Neto. São Paulo: Iluminuras, 2001.

JOYCE, James. Joyce. Música de Câmara. Trad. Alípio Correia de Franca Neto. São Paulo: Iluminuras, 1998.

KEATS, John. Keats, Poemas. Trad. Péricles Eugênio de Silva Ramos. São Paulo: Art Editora, 1985.

KEATS, John. John Keats: Nas Invisiveis Asas da Poesia. Trad. Alberto Marsicano \& John Milton. São Paulo: Iluminuras. 1998. (2oe ed. 2001.)

KEATS, John. John Keats: Ode a um Rouxinol e Ode sobre uma Urna. Trad. Augusto de Campos. Florianópolis: NoaNoa, 1984.

MILTON, John. John Milton, Paraíso Perdido. Trad. Antônio José Lima Leitão. São Paulo: Martin Claret, 2003.

MOORE, Marianne. Marianne Moore, Poemas. Trad. José Antonio Arantes. São Paulo: Companhia das Letras, 1991.

PESSOA, Fernando. Fernando Pessoa, Poemas Ingleses. Trad. Philadelpho Menezes. São Paulo: Experimento, 1993.

PLATH, Sylvia. Sylvia Plath, Poemas. Trad. Rodrigo Garcia Lopes e Maurício Arruda Mendonça. São Paulo: Iluminuras, 1991. (2º ed 1994.) 
PLATH, Sylvia. xxi poemas, Sylvia Plath. Trad. Deisa Chamahum Chaves, Ronald Polito de Oliveira. Mariana: Livre Impressão, 1994.

POE, Edgar Allan. Edgar Allan Poe. "O Corvo" e suas traduçôes. Org. Ivo Barroso. Trad. Baudelaire, Mallarmé, Machado, Emílio de Meneses, Fernando Pessoa, Milton Amado, Alexei Bueno, Gondin de Fonseca, Benedito Lopes. Rio de Janeiro: Nova Aguilar, 1998.

POPE, Alexander. Alexander Pope, Poemas. Trad. Paulo Vizioli. São Paulo: Nova Alexandria, 1994.

POUND, Ezra. Ezra Pound, Os cantos. Trad. José Luis Grünewald. Rio de Janeiro: Nova Fronteira, 1986.

POUND, Ezra. Cantares de Ezra Pound. Trad. Augusto de Campos, D. Pignatari e H. de Campos. Rio de Janeiro: Serviço de Documentação, MEC, 1960.

POUND, Ezra. Ezra Pound, Poesia. Trad. Augusto de Campos, D. Pignatari, H. de Campos. J. L. Grünewald e M. Faustino. São Paulo: Hucitec, 1983.

SHAKESPEARE, William. Shakespeare: 30 Sonetos. Ivô Barroso. Rio de Janeiro: Nova Fronteira, 1991.

SHAKESPEARE, William. Shakespeare. Sonetos. Jorge Wanderley. Rio de Janeiro: Civilização Brasileira, 1991. ( $2^{\circ}$ ed.)

SHAKESPEARE, William. Sonetos de Shakespeare. Péricles Eugênio de Silva Ramos. Rio de Janeiro: Ediouro, s/d.

SHAKESPEARE, William. Shakespeare: Sonetos ao Jovem Desconhecido. Renata Cordeiro. São Paulo: Landy, 2003.

SHELLEY, Percy Bysshe. Shelley. O Triunfo da Vida. Trad. Leonardo Froés. Rio de Janeiro: Rocco, 2001.

STEVENS, Wallace. Wallace Stevens, Poemas. Trad. Paulo Henriques Britto. São Paulo: Companhia das Letras, 1987.

THOMAS, Dylan. Dylan Thomas, Poemas Reunidos 1934-63. Trad. Ivan Junqueria. Rio de Janeiro: José Olympio, 2003.

WALCOTT, Derek. Derek Walcott. Omeros. Trad. Paulo Vizioli. São Paulo: Companhia das Letras, 2000.

WHITMAN, Walt. Walt Whitman, Folhas das Folhas de Relva. 3. ed. Trad. Geir Campos. São Paulo: Brasilense, 1983. 
WhITMAN, Walt. Walt Whitman, Profeta da Liberdade. Trad. Irineu Monteiro. São Paulo: Martin Claret, 1984.

WHITMAN, Walt. Folhas da Relva. Trad. Ramsés Ramos. Brasília: Plana 2001. WILDE, Oscar. Balada do Cárcere de Reading. Trad. Paulo Vizioli. São Paulo: Nova Alexandria, 1995.

WILliams, William Carlos. William Carlos Williams, Poemas. José Paulo Paes. São Paulo: Companhia das Letras, 1987.

WORDSWORTH, William. William Wordsworth. Trad. Paulo Vizioli. São Paulo: Mandacaru, 1988.

YEATS, W. B. Poemas de WB Yeats. Péricles Eugênio da Silva Ramos. São Paulo: Art Editora, 1987.

YEATS, W. B. W B Yeats, Poemas. Paulo Vizioli. São Paulo: Companhia das Letras, 1991.

YEATS, W. B. Tudo que vive é sagrado, William Yeats \& D H Lawrence. Trad. Mário Alves Coutinho. Belo Horizonte: Crisálida, 2001.

\section{Translations from other languages}

\section{Anthologies}

BUARQUE DE HOLANDA, Aurélio. Grandes vozes líricas hispanoamericanas. Rio de Janeiro: Nova Fronteira, 1990.

CAMPOS, Augusto de; CAMPOS, Haroldo de; SCHNAIDERMANN, Boris. Poesia Russa Moderna. São Paulo: Perspectiva, 1985.

GONÇALVES, Aguinaldo J.; ROCA, Juan. M. Antologia Poética Brasil / Colômbia. São Paulo: Edunesp, 1986.

GRÜNEWALD, José Lino. Poetas franceses do século XIX. Trad. José Lino Grünewald. Rio de Janeiro: Nova Fronteira, 1980.

JOZEF, Bella. Poesia Argentina 1940-1960. São Paulo: Iluminuras, 1999.

KOVADLOFF, Santiago. A Palavra Nômade-Poesia Argentina dos anos 70. Trad. Santiago Kovadloff. São Paulo: Iluminuras, 2001.

LARANJEIRA, Mário. Poetas de França Hoje (1945-1995). São Paulo: EDUSP. PERLONGHER, Néstor (Ed.).; BAPTISTA, Josely Vianna. Poesia neobarroca cubana e rioplatense. PERLONGHER, Néstor (Org). Trad. Josely Vianna Baptista. São Paulo: Iluminuras, 2000. 
PIGNATARI, Décio. 31 Poetas 214 Poemas: do Rig-veda e safo a Apollinaire. São Paulo: Companhia das Letras, 1996.

PIGNATARI, Décio. Retrato do amor quando jovem: Dante, Shakespeare, Sheridan, Goethe. São Paulo: Companhia das Letras, 1990.

YUN JUNG IM; MARSICANO, Alberto. O pássaro que comeu o sol. Poesia moderna da Coréia. São Paulo: Arte Pau Brasil, 1993.

ZULAR, Roberto; GALINDEZ JORGE, Verônica. Dois ao Cubo. Alguma Poesia Francesa Contemporânea. São Paulo: Olavobras, 2003.

\section{Individual authors}

AKHMATOVA, Anna. Akhmatova, Anna. Poesia. Porto Alegre: L\&PM, 1990. APOLLINAIRE, Guillaume. Apollinaire, Guillaume. O Bestiário ou o Cortejo de Orfeu. Trad. Álvaro Faleiros. São Paulo: Iluminuras, 2000.

ARETINO. Aretino. Sonetos Luxuriosos. Trad. José Paulo Paes. São Paulo: Companhia das Letras, 2000.

BASHO. Matsuo. Basho, Matsuo. Trilha Estreita ao Confim. Trad. Albeto Marsicano e Kimi Takenaka. São Paulo: Iluminuras, 1997.

BAUDELAIRE, Charles. Baudelaire, Charles. As flores do mal. Trad. Ivan Junqueira. Rio de Janeiro: Nova Fronteira, 1985.

BAUDELAIRE, Charles Baudelaire. Charles. Pequenos poemas em prosa. Trad. Aurélio Buarque de Holanda Ferreira. Rio de Janeiro: Nova Fronteira, 1976.

BAUDELAIRE, Charles. Flores do Mal. Trad. Juremir Machado de Silva. Sulina: Porto Alegre, 1995.

BAUDELAIRE, Charles. As Flores de Mal. Trad. Pietro Nassetti. São Paulo: Matrin Claret, 2004.

BAUDELAIRE, Charles. As Flores do Mal. Trad. Paulo de Carvalho Melo. São Paulo: Círculo do Livro, 1977.

BONNEFOY. Yves. Bonnefoy, Yves. Obra Poética. Trad. Mário Laranjeira. São Paulo: Iluminuras, 1999.

BRECHT, Bertholt. Brecht, Bertholt. Poemas 1913-1956. Trad. Paulo Cesar Souza. Editora 34, 2000. 
CARDENAL, Ernesto. Ernesto Cardenal. As Riquezas Injustas. (Antologia Poética). São Paulo: Círculo do Livro, 1975.

CATUlO. Catulo. O Livro de Catulo. Trad. João Angelo Oliva Neto. São Paulo: EDUSP, 1996.

CELAN, Paul. Paul Celan, Cristal. Trad. Claudia Cavalcanti. São Paulo: Iluminuras. 1994.

CHAR, René. Char, René. O Nu Perdido e outros poemas. Trad. Augusto Contador Borges. São Paulo: Iluminuras, 2001.

CORBIÈRE, Tristan. Corbière, Tristan. Os Amores Amarelos. Trad. Marcos Antônio Siscar. São Paulo: Iluminuras, 1999.

DANTE ALIGHIERI. Divina Comédia. Trad. Cristiano Martins. São Paulo: Itatiaia.

DANTE ALIGHIERI. Divina Comédia. Trad. Flavio Alberti. Porto Alegre: L\&PM, 2004.

DANTE AlighIERI. A Divina Comédia. Trad. Italo Eugênio Mauro. São Paulo: Editora 34, 1998. 3 v.

DANTE AlighiERI. Divina Comédia. Trad. Haroldo de Campos. São Paulo: Centro Italiana de Cultura.

ENZENSBERGER, Hans Magnus. Hans Magnus Enzenberger, Naufrágio do Titanic. Trad. José Marcos Macedo. São Paulo: Companhia das Letras, 1999.

GARCÍA LORCA, Federico. García Lorca, Federico. Romanceiro gitano e outros poemas. Trad. Oscar Mendes. Rio de Janeiro: Nova Fronteira, 1984. GARCÍA LORCA, Federico. Federico Garcia Lorca. Sonetos. Trad. William Agel de Melo. Caxias do Sul: Maneco, 1996.

GARCÍA LORCA, Federico. Federico Garcís Lorca. Obra Poética Completa. 4. ed. Trad. William Agel de Mello. São Paulo: Martin Fontes. 2002.

GELMAN, Juan. Juan Gelman. Agora que serena, termina? Trad. Eric Nepomuceno. Rio de Janeiro: Record, 2001.

GEORGE, Stefan. Crepúsculo. Trad. Eduardo de Campos Valadares. São Paulo: Iluminuras, 1998.

GIRONDO, Oliverio. A Puplia do Zero-Em la masmédula. Trad. Régis Bonvicino. São Paulo: Iluminuras, 1999. 
HOMERO. Homero, Odisséia. Trad. Odorico Mendes. São Paulo: EDUSP, 1992.

HOMERO. Odisséia. Trad. Haroldo de Campos. Ilíada, Arx, 2001.

HORÁCIO. Horácio: Odes e Épodos. Trad. Bento Prado de Almeida Ferraz. São Paulo: Martins Fontes, 2003.

KHAYYAM, Omar. ORubaiyat de Omar Khayyam. Trad. Manuel Bandeira. Rio de Janeiro: Ediouro, sd.

KHAYYAM, Omar. Rubaiyat. Trad. Eugênio Amado. Rio de Janeiro: Garnier, 1999.

KAVÁFIS, Konstantinos. Konstantinos Kaváfis, Poemas. Trad. José Paulo Paes. Rio de Janeiro: Nova Fronteira, 1993.

JELHUN, Bem Tahan. As Cicatrizes do Atlas. Trad. Cláudia Fulluh Balduino Ferreira. Brasília: Universidade de Brasília, 2003.

JUAN DE LA CRUZ. Juan de la Cruz. Pequena Antologia Amorosa. Trad. Marco Luccesi. Rio de Janeiro: Nova Aguilar, 2000.

SOR JUANA DE LA CRUZ. Letras sobre o espelho. Sor Juana de la Cruz. Trad. Vera Mascarenhas de Campos. São Paulo: Iluminuras, 1989.

LAUTRÉAMONT, Conde de. Obra Completa. Trad. Claudio Willer. São Paulo: Iluminuras, 1998.

LI PO \& TU FO. Poemas chineses, de Li Po e Tu Fu. Trad. Cecília Meireles. Rio de Janeiro: Nova Fronteira, 1996.

MAIAKÓVSKI, Vladimir. Maiakóvski, Poemas. 7. ed. Trad. Boris Schnaiderman, Haroldo \& Augusto de Campos. São Paulo: Perspectiva, 2003.

MALLARMÉ, Stéphan. Mallarmé, Poemas. Trad. José Lino Grünewald. Rio de Janeiro: Nova Fronteira, 1984.

MALLARMÉ, Stéphan. Mallarmé. Augusto de Campos, Haroldo de Campos, Décio Pignatari. São Paulo: Perspectiva, 1974.

MONTAle, Eugênio. Diário Postumo. Trad. Geraldo Holand Cavalvanti. Rio de Janeiro: Record, 1997.

MiChelangelO. Michelangelo, Poemas. Trad. Nilson Moulin. Rio de Janeiro: Imago, 1994. 
MILOSZ, Czestaw. Czestaw Milosz. Não Mais. Brasília: Universidade de Brasília. Coleção Poetas do Mundo. Ed. Henryk Siewierski, 2002.

MONTEJO NAJAS, Adolfo. Adolfo Montejo Najas, Pedras Pensadas. Trad. Sergio Alardes. São Paulo: Ateliê, 2002.

NERUDA, Pablo. Neruda, Pablo, Cem Sonetos do Amor. Porto Alegre: L\&PM, 1990.

NERUDA, Pablo. Neruda, Pablo, Barcarola. Porto Alegre: L\&PM, 1992.

NERUDA, Pablo. Neruda, Pablo. Presente de um Poeta. Trad. Thiago de Mello. São Paulo: Vergana e Ribas, 2001.

NERUDA, Pablo. Pablo Neruda. Canto Geral. Trad. Paulo Mendes Campos. Rio de Janeiro: Ed. Brasil, 2002.

NERUDA, Pablo. Pablo Neruda. Cadernos de Temuco. 2. ed. Trad. Thiago de Mello. Rio de Janeiro: Bertrand Brasil, 2000.

NERUDA, Pablo. Os Versos do Capitão. Trad. Thiago de Mello. Rio de Janeiro: Bertrand Brasil, 2003.

NERUDA, Pablo. Vinte Poemas de Amor. 32. ed. Trad. Domingos Carvalho da Silva. Rio de Janeiro: José Olympio, 2004.

OvíDIO. Ovídio, Poemas de Carne e Exílio. Trad. José Paulo Paes. São Paulo: Companhia das Letras, 1990.

PÂVlOVITCH, Miodrag. Miodrag Pâvlovitch. Bosque da Maldição. Trad. Aleksander Jovanovic. Brasília: Universidade de Brasília, 2003.

PONGE, Francis. O Partido das Coisas. Trad. Ignacio Antonio Neis e Michel Peterson. São Paulo: Iluminuras, 1995.

PONGE, Francis. A Mesa. Trad. Ignácio Antônio Neis e Michel Peterson. São Paulo: Iluminuras, 1999.

PRÉVERT, Jacques. Jacques Prévert: Poemas. Trad. Silviano Santiago. Rio de Janeiro: Nova Fronteira, 2000.

RILKE, Rainer Maria. Coisas e Anjos de Rilke. Trad. Augusto de Campos. São Paulo: Perspectiva, 2001.

RIMBAUD, Arthur. Gravuras Coloridas. Trad. Rodrigo Garcia Lopes e Maurício Arruda Mendonça. São Paulo: Iluminuras, 1993.

SAFO DE LESBOS. Safo de Lesbos. Poemas e Fragmentos. Trad. Joaquim Brasil Fontes. São Paulo: Estação Liberdade, 1991. 
SÉFERIS, Giórgos. Seféris, Giórgos - Poemas. Trad. José Paulo Paes. São Paulo: Nova Alexandria.

SIJÔ. Sijô. Trad. Albeto Marsicano e Yun Jung Im. São Paulo: Iluminuras, 1994.

SOLOMON, Carl. Solomon, Carl. De Repente Acidentes. Porto Alegre: L\&PM.

TRAKL, George. De Profundis e outros poemas. Trad. Claudia Cavalcanti. São Paulo: Iluminuras, 2000.

UNGARETTI, Giuseppe. Ungaretti. Daquela estreita à outra. Trad. Haroldo de Campos \& Aurora Bernardini. São Paulo: Ateliê, 2003.

UNGARETTI, Giuseppe. Ungaretti. A Alegria. Trad. Geraldo Holand Cavalcanti. Rio de Janeiro: Record, 2003.

VILLON, François. Poesia. Trad. Sebastião Uchoa Leite. São Paulo: EDUSP.

VILLON, François. Villon, Testamento. Trad. Afonso Felix de Souza. São Paulo: Itatiaia, 1987.

\section{Other references}

ARROJO, Rosemary. Paulo Vizioli e Nelson Ascher discutem John Donne: a que são fiéis tradutores e críticos de tradução? In: Tradução $e$ Comunicação. Faculdade Ibero-Americana de Letras e Ciências Humanas, São Paulo, n. 9, dez. 1986.

CAMPOS, Haroldo de. Deus e o Diabo no Fausto de Goethe. São Paulo: Perspectiva, 1981.

HIRSCH, Irene. História dos EUA: Made in Brazil. Ph. D. thesis, FFLCH USP, 2002.

MILTON, John. Tradução: Teoria e Prática. São Paulo: Martins Fontes, 1998. MILTON, John. Augusto de Campos e Bruno Tolentino: a Guerra das Traduções. In: Cadernos de Tradução. G. T. de Tradução. Universidade Federal de Santa Catarina, n. 1, p. 13-26, 1996. 